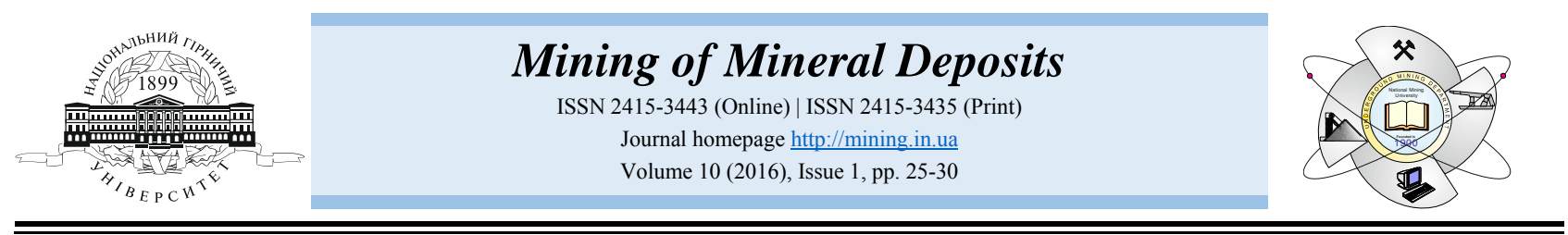

UDC 622.831

http://dx.doi.org/10.15407/mining10.01.025

\title{
DESTRUCTION OF ROCKS BY THE NON-EXPLOSIVE DEPLETING COMPOUNDS DURING MINING
}

\author{
S. Sakhno ${ }^{1}$, B. Kobylianskyi², I. Sakhno ${ }^{1 *}$ \\ ${ }^{1}$ Department of Mineral Deposits, Donetsk National Technical University, Krasnoarmiisk, Ukraine \\ ${ }^{2}$ Department of Occupational and Environmental Safety, Teaching and Research Professional Pedagogical Institute, Ukrainian \\ Engineering and Pedagogical Academy, Bakhmut, Ukraine \\ *Corresponding author: e-mailsahnohuan@gmail.com,tel.+380501659852
}

\section{РУЙНУВАННЯ ПОРІД НЕВИБУХОВИМИ РУЙНУЮЧИМИ СУМІШАМИ ПРИ ПРОВЕДЕННІ ГІРНИЧИХ ВИРОБОК}

\author{
С. Сахно ${ }^{1}$ Б. Кобилянський ${ }^{2}$, І. Сахно ${ }^{1 *}$ \\ ${ }^{1}$ Кафедра розробки родовищ корисних копалин, Донецький Національний технічний університет, Красноармійськ, Украӥна \\ Кафедра охорони праиі та екологічної безпеки, Навчально-науковий професійно-педагогічний інститут Української \\ інженерно-педагогічної академії, Бахмут, Украӥна \\ *Biдповідальний автор: e-mail sahnohuan@gmail.com, тел. +380501659852
}

\begin{abstract}
Purpose. Justification of the possibility of non-explosive coherent rocks destruction while carrying out stratal underground mine workings on the basis of the set of dependencies describing changes in physical and mechanical properties of the non-explosive depleting compounds (NDC) during hydration process in the blast-hole charges in relation to crack growth in the adjacent area.

Methods. By conducting experiments on the unequal component triaxial compression unit, we obtained the dependence of changes in the physical and mechanical properties of the NDC on the hydration time and the relationships between the physical and mechanical properties. The required distance between the blast-holes with NDC was established analytically for non-explosive destruction by quasi-static pressure of the compound expansion.

Findings. The study allowed to obtain empirical dependences of medium stress change, coefficient of transverse strain, strain modulus of the NDC for compound expansion in time. The dependence of the strain modulus of the NDC on medium stress has been established. The research resulted in the analytical dependence of the length of the crack progressing from the blast-hole walls into the massif depth while implementing non-explosive technologies of destruction on the compound expansion pressure, its elastic constants as well as physical and mechanical characteristics of the medium under destruction.

Originality. Medium stresses caused by the NDC expansion grow in time similarly to the growth of the stress tensor components, the dependence of the strain modulus on average stresses being satisfactorily described by an exponential dependence.

Practical implications. The results of experimental and theoretical studies, taking into account sufficient accuracy for practical applications, can be used to determine parameters of the quasi-static rocks breaking by non-explosive compound during stratal mining.
\end{abstract}

Keywords: rocks, non-explosive depleting compound, hydration, carrying out, blast-hole, destruction, pressure, strains

\section{INTRODUCTION}

Technological cycles of mining include the operations in rock destruction, taking the rocks away from the face, mounting and maintenance of excavations within the exploitation period. The speed and costs of conducting greatly depend on the destruction techniques. The destruction of rocks during mining is produced by the mechanical (drilling) and blasting methods. Under other equal conditions, the explosive destruction becomes less preferred due to lower mining rates and higher costs and time consumption. Drilling and blasting works (DBW) lead to softening of the marginal rocks and causes strengthening of convergence and premature deformation of the support (Krukovskiy \& Krukovskaya, 2012).

However, in some cases, for example, while carrying out excavations on the rocks with hardness more 
than 6 items in accordance with Prof. Protodiakonov's scale or on outburst-prone coal and sandstone strata, the use of mechanical destruction methods becomes restricted (Royenko \& Kharin, 2015). Therefore, in spite of the intensive development of the tunneling machinery and complexes the share of drilling and blasting is currently over $50 \%$.

It should be noted that the use of the explosive destruction methods is associated with the special security and safety mode because DBW is a potentially dangerous factor. The injury analysis in coal mining shows that the share of accidents caused by blasting operations makes up approximately one percent.

However, such accidents at gassy mines can bring about larger tragedies because of the gas-dynamic phenomenon, e.g. gas explosion caused by the local strata congestion at A.F. Zasiadko mine on June 31, 2002.

The main reasons of accidents and injuries caused by explosives at mines are:

- unauthorized conduction of blasting operations or violation of their DBW certificates;

- blasting works in the presence of people in the dangerous zone;

- use of such explosives at coal mines that do not comply with safety grade;

- carrying out DBW by the staff without the appropriate qualifications or the right to conduct such works.

The analysis shows that over $80 \%$ of accidents in industry are caused by administrative reasons and only $20 \%$ are associated with violation of the DBW certificates (reduced detonator quantities, overhead charges, incompliance of explosives with safety grades).Thus, implementation of explosives of safety grades V and VI does not solve the problems of safety.

Furthermore, according to the available data (Shevtsov, Kalyakin, Kutsenko, Shkumatov \& Rublova, 2009), blasting a kilogram of $10 \mathrm{~A}$ detonit or $6 \mathrm{LH}$ ammonit results in discharge of poisonous gases respectively: $\mathrm{CO}-37-45$ and $49-57 \mathrm{dm}^{3} / \mathrm{kg}$, and nitrogen oxides $1.4-3.6$ and $1.3-1.5 \mathrm{dm}^{3} / \mathrm{kg}$. Given the lack of dustprotection tools the air dustiness reaches from 15 up to $40 \mathrm{mg} / \mathrm{m}^{3}$. So, DBW is a major factor of environmental pollution. TNT is not only dangerous due to its explosive properties, but also as a toxic product that causes thirty various diseases to human body (Stupnik, Kalinichenko, Fedko \& Mirchenko, 2013).

Hence there is a need to develop a new tool for breaking the rocks without producing dynamic effects onto the massif. Non-explosive depleting compounds (NDC) can be used as such agents. These are substances (mixtures and compounds) whose chemical hydration is accompanied by mechanical strains in the host environment without combustion and detonation. Most modern NDCs contain calcium oxide as their basic component. Its hydration is followed by sharp increase in volume. (Metha, 2012; Yamazaki, Kamiaka, Kobayashi \& Hirose, 1980). Therefore, when the NDC is placed in the closed cavity, it exercises pressure impact onto its walls due to the mixture expansion.

\section{THE MAIN PART OF THE ARTICLE}

Currently, the industry of Ukraine manufactures nonexplosive depleting substance NDS-80 that comprises the ground products of the carbonate rocks' (together with special admixtures) calcination.

Sakhno analyzes the NDS-80 properties and studies the development of new NDS-compositions for coal mines. She also notes that the maximum expansion pressure developed by the NDC in blast-hole charge at ambient temperature between $25-35^{\circ} \mathrm{C}$ can reach $80 \mathrm{MPa}$. It gives a possibility to regard such compounds as an effective tool for the solid rock depletion (Sakhno, 2013).

However, the above described mixtures can work effectively only in presence of two available surfaces. Since it is impossible to conduct DBW directly in the fore-head, the face should be preliminarily exposed. Technically, such approach does not present any difficulty. It involves coal extraction by any method - e.g. by niche cutting machine or operating member of a roadheader. The subsequent breaking of the host rocks is done by drilling blast holes in rows that extend in parallels to the plane of exposure formed as a result of mineral extraction and placing the NDC in them by means of loading shattered rocks onto the vehicle. In this case it is advisable to take the length of the blast holes in the range between $0.5-3 \mathrm{~m}$. The essence of the method is presented in Figure 1.

(a)

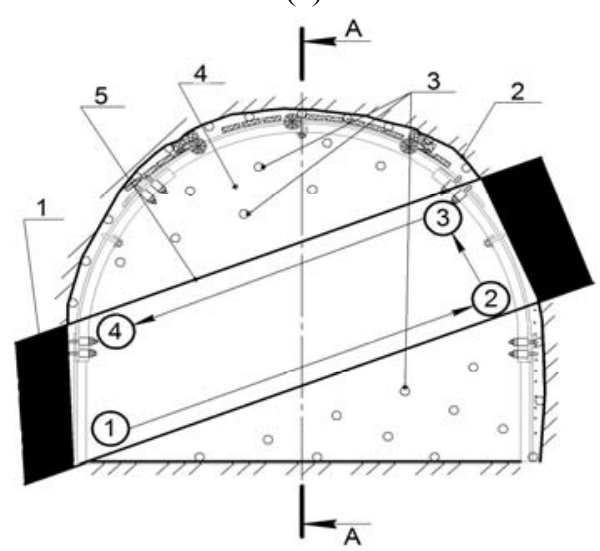

(b)

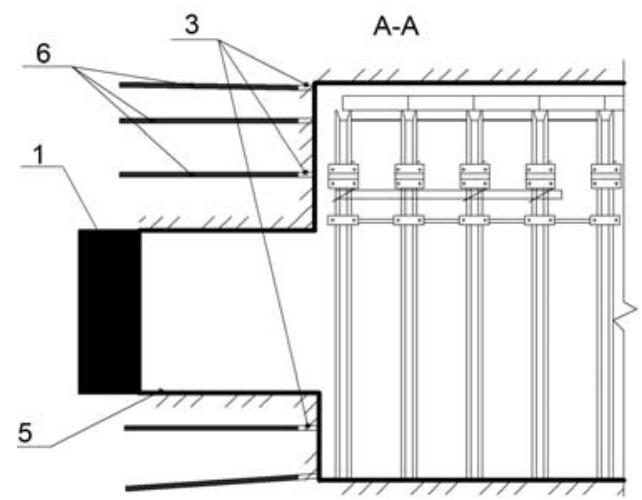

Figure 1. Method of mining: (a) processing circuit face in cross section; (b) a longitudinal sectional view of near face part of working; 1 -mineral resource; 2 -conducted roadway (working); 3 -blast-holes; 4-host rocks; 5 -exposure plane formed as a result of mineral resource extraction; 6 - NDC 
Breaking the host rocks by using NDC can be performed due to quasi-static pressure developed by their expansion. It allows to ensure the destruction of rocks in the face while minimizing the rock stratification in adjacent marginal zones. Thus, the stability of mine working is achieved at the expense of preserving the natural strength and bearing capacity of the host rocks.

Drilling blast holes in rows, arranged parallel to the plane of exposure formed as a result of mineral excavation, provides uniform destruction of rocks in the roadway section.

In order to determine the distances between the rows of blast holes, as well as the distance between the blast-holes in the rows and the blast-holes of the margin roadway (working) it is necessary to use the approach based on adequate reflection of the quasi-static fracture mechanism.

The analysis of modern ideas about the destruction of solid bodies shows that characteristics of rocks destruction with the help of NDC can be studied on the basis of the Griffiths - Irwin's local power criterion (Kostandov, Makarov, Yeremin, Shipovskii \& Smolin, 2012). From this perspective, the following solution can be suggested.

Let us consider the elementary volume of circular cross-section blast-hole with radius $r_{0}$ and a part of the blast-hole accommodating massif in the near face area that is enclosed within parallel planes oriented normally to the axis of the blast-hole with the inter-plane distance $\Delta h$ (Fig. 2).

(a)

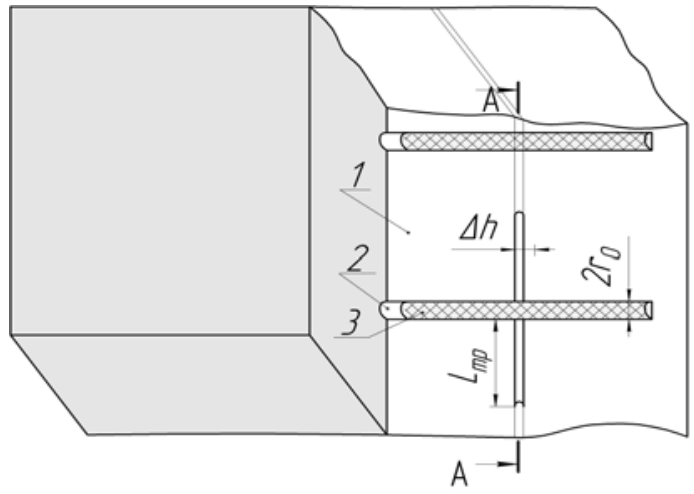

(b)

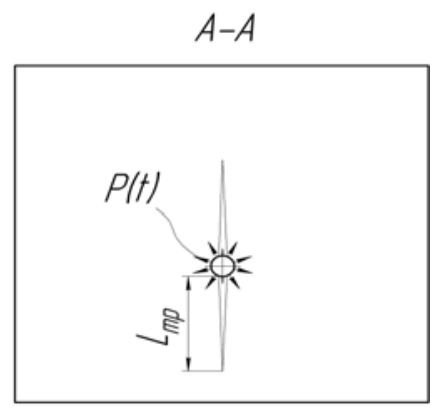

Figure 2. Diagram for calculating destruction parameters with the help of NDC: (a) general view; (b) longitudinal sectional view; 1 - the object under destruction; 2 - blast-hole; 3 - NDC
If due to the NDC expansion in the volume of the blast-hole $\Delta V$ :

$\Delta V=\pi r_{0}^{2} \Delta h$

a quasi-hydrostatic pressure equal to the pressure of expansion $P$ over time $t$ arises just before the destruction:

$\sigma_{1 n d c}=\sigma_{2 n d c}=\sigma_{3 n d c}=P$.

We know that the hardened NDC material is isotropic and has a modulus of elasticity $E_{N D C}$, which allows to express the elastic deformation energy of the volume element in the form:

$$
\begin{aligned}
& U=\frac{1}{2 E_{N D C}}\left(\sigma_{1 n d c}^{2}+\sigma_{2 n d c}^{2}+\sigma_{3 n d c}^{2}-2 \mu_{N D C} \times\right. \\
& \left.\times\left(\sigma_{1 n d c} \sigma_{2 n d c}+\sigma_{2 n d c} \sigma_{3 n d c}+\sigma_{3 n d c} \sigma_{1 n d c}\right)\right) \cdot \Delta V,
\end{aligned}
$$

where:

$E_{N D C}$ - elasticity modulus of NDC, MPa;

$\sigma_{1 n d c}, \sigma_{2 n d c}, \sigma_{3 n d c}-$ principal stresses in NDC, MPa;

$\mu_{N D C}$ - NDC lateral deformation modulus.

Let us assume that this volume is affected from the outside by the field of stresses $\sigma_{1}, \sigma_{2}, \sigma_{3}$, taking into account (3):

$$
\begin{aligned}
& U=\frac{1}{2 E_{N D C}}\left(\left(P^{2}+\sigma_{1}^{2}\right)+\left(P^{2}+\sigma_{2}^{2}\right)+\left(P^{2}+\sigma_{3}^{2}\right)+2 \mu_{N D C} \times\right. \\
& \left.\times\left(\left(P^{2}+\sigma_{1} \sigma_{2}\right)+\left(P^{2}+\sigma_{2} \sigma_{3}\right)+\left(P^{2}+\sigma_{3} \sigma_{1}\right)\right)\right) \cdot \Delta V .
\end{aligned}
$$

To simplify the calculations, we replace the multiplier $\left(P^{2}+\sigma_{1}^{2}\right)+\left(P^{2}+\sigma_{2}^{2}\right)+\left(P^{2}+\sigma_{3}^{2}\right)-2 \mu_{N D C} \times$ $\times\left(\left(P^{2}+\sigma_{1} \sigma_{2}\right)+\left(P^{2}+\sigma_{2} \sigma_{3}\right)+\left(P^{2}+\sigma_{3} \sigma_{1}\right)\right)$, by $Q^{2}$. Then, considering (4) we obtain:

$U=\frac{Q^{2}}{2 E_{N D C}} \cdot \pi r_{0}^{2} \Delta h$.

Following Griffith's energy criterion, we assume that due to the crack spreading in two opposite directions from the blast-hole axis the stress state in the volume element of NDC is completely eliminated and energy is spent on open air formation:

$\Delta S=4 \gamma_{p} \Delta h L_{c r}$,

where:

$\gamma_{s}$ - the surface energy of the rock, $\mathrm{J} / \mathrm{m}^{2}$;

$L_{c r}$ - crack length, $\mathrm{m}$.

Then, the energy balance equation (5), together with the expression (6), can be written as:

$\frac{Q^{2}}{2 E_{N D C}} \cdot \pi r_{0}^{2} \Delta h=4 \gamma_{s} \Delta h L_{c r}$. 
Thus, we can obtain an expression for the length of the crack:

$$
L_{c r}=\frac{Q^{2} \cdot \pi \cdot r_{0}^{2}}{8 E_{N D C} \cdot \gamma_{s}} .
$$

In engineering calculations, crack resistance of soild bodies is not characterized by the surface energy, but by a stress intensity factor $K_{I}$. In the case under study, the crack growth is caused by tensile stresses in the direction orthogonal to the axis of the crack, i.e. those are normal tension cracks. Hence, the stress intensity factor $K_{I}$ can be expressed in terms of elastic modulus and surface energy:

$$
K_{I}=\sqrt{2 E_{M} \gamma_{s}}
$$

where:

$E_{M}$ - elastic modulus of the rock, MPa.

Substituting (9) into (8) gives the expression for the crack length, written in the form:

$$
L_{c r}=\frac{Q^{2} \cdot \pi \cdot r_{0}^{2} E_{M}}{4 E_{N D C} \cdot K_{I}^{2}} \text {. }
$$

After inverse substitution of $Q^{2}$, we obtain:

$$
\begin{aligned}
& L_{c r}=\frac{1}{4 E_{N D C} \cdot K_{I}^{2}}\left(\left(P^{2}+\sigma_{1}^{2}\right)+\left(P^{2}+\sigma_{2}^{2}\right)+\left(P^{2}+\sigma_{3}^{2}\right)-\right. \\
& \left.-2 \mu_{N D C}\left(\left(P^{2}+\sigma_{1} \sigma_{2}\right)+\left(P^{2}+\sigma_{2} \sigma_{3}\right)+\left(P^{2}+\sigma_{3} \sigma_{1}\right)\right)\right) \times \\
& \times \pi \cdot r_{0}^{2} E_{M} .
\end{aligned}
$$

Assuming that the elastic recovery of rocks occurs in the margin area, the impact of external stresses can be neglected and the formula (11) will be changed into:

$$
L_{c r}=\frac{3 P^{2} \pi \cdot r_{0}^{2} E_{M}}{8 E_{N D C} \cdot K_{I}^{2}}\left(1-2 \mu_{N D C}\right)
$$

where:

$P$ - a pressure of NDC in the blast-hole, MPa;

$r_{0}$ - a circular cross-section blast-hole radius, $\mathrm{m}$;

$E_{M}$ - elastic modulus of the rock, $\mathrm{MPa}$;

$E_{N D C}$ - elastic modulus of NDC, MPa;

$K_{I}-$ stress intensity factor, $\mathrm{MPa}(\sqrt{m})$;

$\mu_{N D C}$ - lateral deformation modulus of NDC.

In the aforesaid dependence, the values $E_{M}, K_{I}$ characterize the features of the blasted object, where $E_{M}$ is the constant of the material and it can be determined experimentally. The stress intensity factor $K_{I}$ can be determined according to the normative document.

The values $E_{N D C}, \mu_{N D C}$ and $P$ can be determined experimentally for a specific type of the NDC applied. In the proposed method, the blast-holes with NDC are drilled into the unbroken massif. Thus, at some distance from the hole mouth, we get the conditions limiting NDC movement along all axes.
The physical and mechanical properties of the NDC during the expansion were researched with the help of laboratory facility for non-uniform triaxial compression (NUTC), which recorded the pressure and motions along three axes. In order to analyze the obtained experimental data, to determine physical and mechanical properties of the NDC and its damageability rate, the principal mechanical features were calculated.

The plasticized NDC were taken as samples for testing. The volume of the compound equalled to the volume of a cube with $55 \mathrm{~mm}$ side, and the mass of $0.385 \mathrm{~kg}$. The research was supposed to be carried out on a sample of the unit length and volume scaled 1:1. The sample was placed into the test chamber with the retracted horizontal plates. Then, in order to ensure the reliable closing contact, the sample was squeezed with the help of the upper press plate until the chamber got closed (Fig. 3).

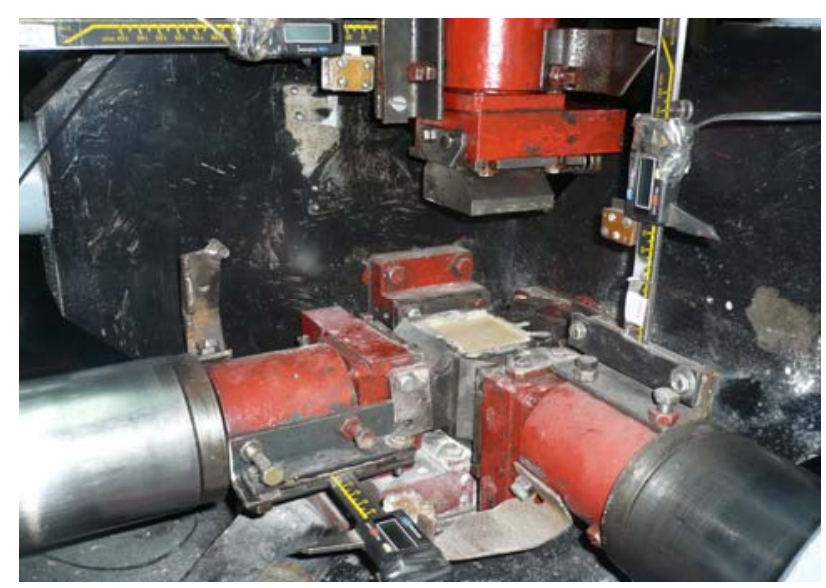

Figure 3. The plasticized NDC in the NUTC test chamber

The tests were carried out in the set deformation mode. After the sample was placed into the operation chamber, the expansion pressure increased during the calcium oxide crystallization, which caused the displacement of the press plates; the appropriate pressure plates being kept in the predetermined range of deformation by smooth compression. The ambient temperature in the experiments ranged from 21 to $22.5^{\circ} \mathrm{C}$. When the experiment was over, the NDC hardened cube edges were measured with a caliper (division value $0.05 \mathrm{~mm}$ ).

The results of the experiment served as a source of information for calculating physical and mechanical characteristics of NDC during its expansion. The calculation results during the first 8 hours after the NDC preparation are presented by the graphs in Figures 4 and 5 .

The graphs show that the average stresses caused by the NDC expansion grow over time in a character similar to the stress tensor components rise, and in 5 hours after the NDC preparation reach $37 \mathrm{MPa}$.

The lateral deformation rate of the NDC expansion varies from 0.19 to 0.3 , making up on average 0.257 . The deformation modulus increases with time and reaches its maximum of $120 \mathrm{GP}$, and the modulus of deformation growth correlates with that of medium stress caused by the expansion. The latter is satisfactorily described by the exponential dependence of $E=1987.3 e^{0,1182 \sigma_{\text {middle }}}$ (Fig. 5). 
(a)

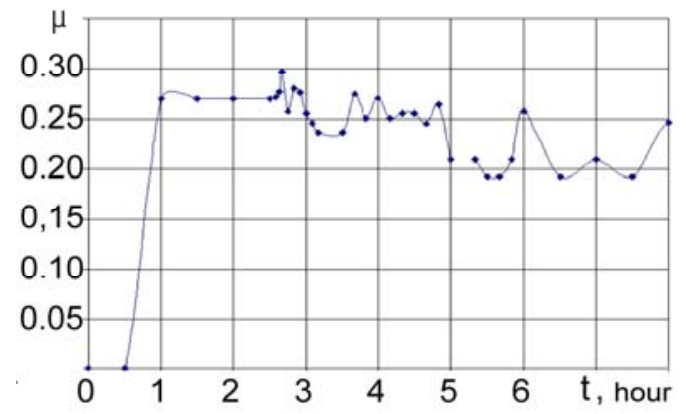

(b)

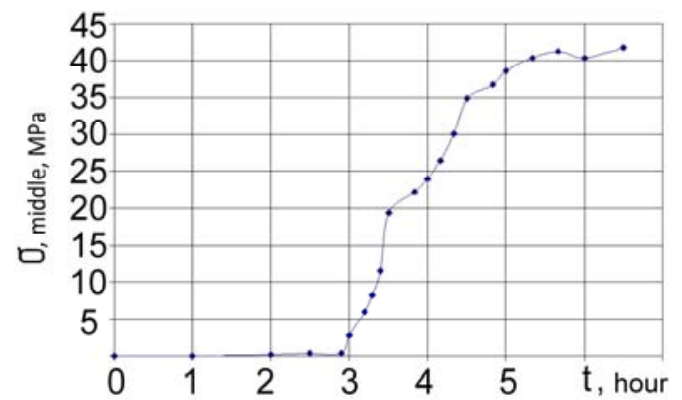

Figure 4. Change of the average stress (a) and transverse deformation rate (b) for the NDC expanding in time

(a)

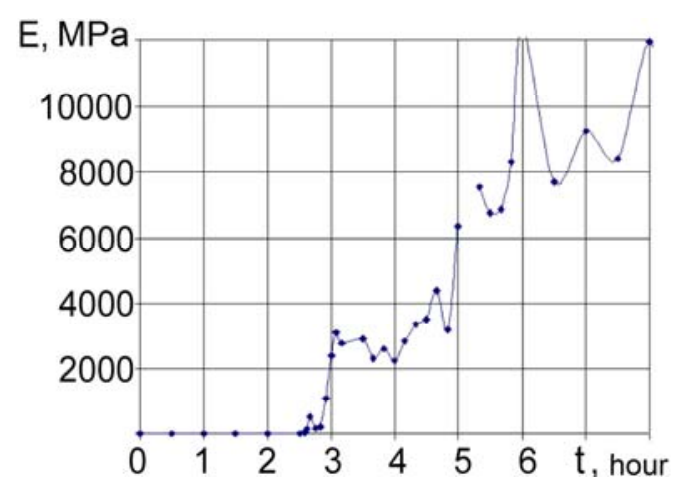

(b)

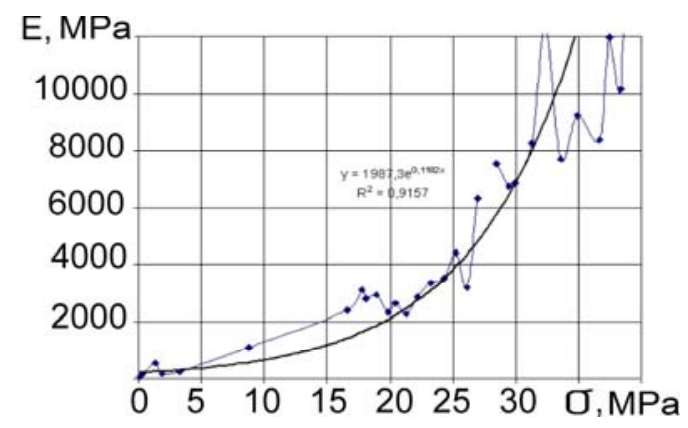

Figure 5. The NDC deformation module change in time (a) and the NDC deformation module dependence on the average stress (b)

Such high values of the deformation modulus are explained by the load program, because the deformation was kept close to zero (within the experiment error), and the stresses tend to rise due to expansion.

\section{CONCLUSIONS}

Thus, the experimental researches confirmed that the module of the lateral deformation under the NDC expansion can be adopted from 0.205 to 0.275 . The value of the NDC elasticity modulus should be taken from 20 to 30 GP. The NDC pressure expansion within 24 hours was $57 \mathrm{MPa}, 75 \%$ of which developed during the first 8 hours.

The obtained results can be used for calculating the rock destruction parameters for implementing the nonexplosive depleting compounds at workings.

\section{ACKNOWLEDGEMENTS}

The authors express their gratitude to the staff of the Institute of Physics of Mining Processes, personally to Professor Volodymyr Griniov and researcher Andrew Molodetskie for their support and assistance during research conducted at the Institute.

\section{REFERENCES}

Kostandov, Yu., Makarov, P., Yeremin, M., Shipovskii, I., \& Smolin, I. (2012). Simulation for failure of fragile and quasi-fragile bodies and geo-environments, Fizicheskaya Mezomekhanika, 15(3), 35-44.

Krukovskiy, A., \& Krukovskaya, V. (2012) Research of the stress condition of massif around mine working with bolting at the drive working by blast-hole drilling, Naukovyi Visnyk Natsionalnoho Hirnychoho Universytetu, (1), 34-40.

Metha, P. (1973) Mechanism of expansion associated with ettringite formation. Cement and concrete research, (3), 1-6.

Royenko, A., \& Kharin, S. (2015) Study of influence of explosion on deep layers construction intensity by means of object-oriented programming Naukovyi Visnyk Natsionalnoho Hirnychoho Universytetu, (1), 61-66.

Sakhno, I. (2013) Research of mechanism of the directed destruction of mountain breeds by in explosive destroying mixtures. Naukovyi Visnyk Natsionalnoho Hirnychoho Universytetu, (6), 20-26.

Shevtsov, M., Kalyakin, S., Kutsenko, I., Shkumatov, O., \& Rublova, O. (2009). Stan tekhnologii ta obhruntuvannia umov ruinuvannia sutsilnoho seredovyshcha hirskykh porid i budivelnykh konstruktsii. Problemy hirskoho tysku. Donetsk: National Technical University, (17), 226-249.

Stupnik, N., Kalinichenko, V., Fedko, M., \& Mirchenko, Ye. (2013) Prospects of application of tnt-free explosives in ore deposits developed by underground mining. Naukovyi Visnyk Natsionalnoho Hirnychoho Universytetu, (1), 24-48.

Yamazaki, Y., Kamiaka, H., Kobayashi, S., \& Hirose, T. (1980). Expansion mechanism and hydration of expansive cement. In CAJ Review of the 34th General Meeting (Vol. 34, pp. 59-61). 


\section{ABSTRACT (IN UKRAINIAN)}

Мета. Обгрунтування можливості невибухового руйнування міцних гірських порід при проведенні пластових підземних гірничих виробок, виходячи зі встановлених залежностей зміни фізико-механічних властивостей невибухових руйнуючих сумішей (НРС) у процесі гідратації в шпурових зарядах на ріст тріщин в навколошпуровой області.

Методика. Експериментальним шляхом на установці нерівнокомпонентного тривісного стиску встановлена залежність зміни фізико-механічних властивостей НРС від часу гідратації, а також зв'язок між фізикомеханічними властивостями. Аналітично встановлено необхідну відстань між шпурами з НРС при реалізації невибухового руйнування квазистатичним тиском розширення суміші.

Результати. Отримано емпіричні залежності зміни середньої напруги, коефіцієнта поперечної деформації, модуля деформації НРС при розширенні суміші у часі. Встановлено залежність модуля деформації НРС від середньої напруги. Отримано аналітичну залежність довжини тріщини, що розвивається від стінок шпуру вглиб масиву при реалізації технології невибухового руйнування від тиску розширення суміші, iї пружних констант i фізико-механічних властивостей середовища, що руйнується.

Наукова новизна. Середні напруження, викликані розширенням НРС, ростуть у часі за характером аналогічно росту компонентів тензора напружень, при цьому залежність модуля деформації від середніх напружень задовільно описується експоненціальною залежністю.

Практична значимість. Отримані результати експериментальних і теоретичних досліджень, 3 достатньою для практичного застосування точністю, можуть використовуватися для визначення параметрів квазістатичного руйнування гірських порід невибуховими сумішами при проведенні пластових гірничих виробок. Це істотно підвищить безпеку робіт, розширить область невибухового проведення на породи з високою міцністю.

Ключові слова: гірські породи, невибухова руйнуюча суміш, гідратація, проведення, шпур, руйнування, тиск, напруження

\section{ABSTRACT (IN RUSSIAN)}

Цель. Обоснование возможности невзрывного разрушения прочных горных пород при проведении пластовых подземных горных выработок, исходя из установленных зависимостей изменения физико-механических свойств невзрывчатых разрушающих смесей (НРC) в процессе гидратации в шпуровых зарядах на рост трещин в околошпуровой области.

Методика. Экспериментальным путем на установке неравнокомпонентного трехосного сжатия установлена зависимость изменения физико-механических свойств НРС от времени гидратации, а также связь между физико-механическими свойствами. Аналитически установлено необходимое расстояние между шпурами с НРС при реализации невзрывного разрушения квазистатическим давлением расширения смеси.

Результаты. Получены эмпирические зависимости изменения среднего напряжения, коэффициента поперечной деформации, модуля деформации НРС при расширении смеси во времени. Установлена зависимость модуля деформации НРС от среднего напряжения. Получена аналитическая зависимость длины трещины развивающейся от стенок шпура вглубь массива при реализации технологии невзрывного разрушения от давления расширения смеси, ее упругих констант и физико-механических свойств разрушаемой среды.

Научная новизна. Средние напряжения, вызванные расширением НРС, растут во времени по характеру аналогично росту компонентов тензора напряжений, при этом зависимость модуля деформации от средних напряжений удовлетворительно описывается экспоненциальной зависимостью.

Практическая значимость. Полученные результаты экспериментальных и теоретических исследований, с достаточной для практического применения точностью, могут использоваться для определения параметров квазистатического разрушения горных пород невзрывчатыми смесями при проведении пластовых горных выработок. Это существенно повысит безопасность работ, расширит область невзрывного проведения на породы с высокой прочностью.

Ключевые слова: горные породы, невзрывчатая разрушающая смесь, гидратация, проведение, шпур, разрушение, давление, напряжения

\section{ARTICLE INFO}

Received: 7 October 2015

Accepted: 19 November 2015

Available online: 30 March 2016

\section{ABOUT AUTHORS}

Svitlana Sakhno, Assistant Professor of the Department of Mineral Deposits, Donetsk National Technical University, 2 Shibankova Ave., 85300, Krasnoarmiisk, Ukraine. E-mail: sahnohuan@gmail.com

Borys Kobylianskyi, Candidate of Technical Sciences, Assistant Lecturer of the Occupational and Environmental Safety, Teaching and Research Professional Pedagogical Institute Ukrainian Engineering and Pedagogical Academy, 9a Nosakova Ave., 84500, Bakhmut, Ukraine. E-mail: b.kobiliansky@yandex.ua

Ivan Sakhno, Doctor of Technical Sciences, Professor of the Department of Mineral Deposits, Donetsk National Technical University, 2 Shibankova Ave., 85300, Krasnoarmiisk, Ukraine. E-mail: sahnohuan@gmail.com 